UDC 378.147:37.091.113]:[004.032.6:005.336.2]:[001.895:008]

DOI: https://doi.org/10.33989/2075-146x.2019.24.194845

DMYTRO KOZLOV

ORCID ID 0000-0003-1875-0726

A.S. Makarenko Sumy State Pedagogical University

\title{
DEVELOPMENT OF PERSONALITY INNOVATIVE CULTURE: MODERN PHILOSOPHICAL AND PEDAGOGICAL DISCOURSE
}

The article is devoted to determining the essence of the process of development of personality innovative culture. The phenomenon of innovative culture of the future manager of educational institution has been studied. The study considers the place of the innovative culture of the future manager of the educational institution in its components system. Great attention has been given to disclosing the dialectical and synergistic understanding of the personality innovative culture. The innovative personality culture in the context of the paradigm of humanity sustainable development has been characterized. It has been stated that the educational system of any country is the national foundation of society innovative development. Only a high level of education provides a significant rate of innovation progress. This is evidenced by the rapid development of countries with advanced education systems that have made a significant innovation breakthrough, thanks to a powerful advance in the application of the latest educational technologies and principles. It is emphasized on the development of personality innovative culture in the context of philosophical and pedagogical discourse.

Keywords: development, sustainable development, innovation, personality innovative culture, dialectical and synergistic principles of development of personality innovative culture.

\section{Introduction.}

The problem of development and self-development of an individual becomes of utmost importance nowadays, when society is in continuous search for trajectories of global, national, professional and individual development. Moreover, the modern world sets clear criteria for social development, which are reflected in terms, such as "sustainable development", "environmental progress", "innovative progress" and others. State and political leaders, philosophers, educators, and scholars focus on issues of purpose, direction and future development of humanity, vectors and strategies of movement, its road map, priority measures, criteria and indicators of progress, etc. (Weizsaker, Wykman, 2019; Ukraine-2020 Sustainable Development Strategy, 2015). The society stands in solidarity in the opinion of the priority of innovative development of all activity spheres: from economic and administrative, to educational and cultural. The indifferent minority of humanity calls for the creation of the innovative ecosystem and the right conditions for the development of economic and technological innovation.

In covering the content and ways of innovative development, the notion of "innovative culture", of which social formation is regarded as a key indicator of the progress in the 21 st century, is of essential importance. Thus, the approved by the Cabinet of Ministers of Ukraine "Strategies for the Development of Innovative Activity Sphere for the Period up to 2030 " states that the current stage of socio-cultural development requires a strategic vision and a consistent state policy on the transition of Ukraine to the innovative path of development, formation of the national innovation ecosystem, which would ensure its implementation and increase the development of innovative culture in the state (On approval of the Strategy for the Development of the Sphere of Innovative Activity for the period till 2030).

Consequently, there is a need for a comprehensive analysis of the problem research of the development of personality innovative culture: modern philosophical and pedagogical discourse.

\section{Analysis of relevant research.}

Special attention is paid to the scientific discussion on the relation between the human-creating context of the concepts of "development" and "formation". Moreover, the analysis of the problems of modern pedagogical researches shows that when studying any pedagogical problem, scientists V. Andruschenko, I. Zyazyun, V. Kremen, O. Savchenko, N. Nychkalo and others are obliged to consider it in the development context. In the context of the raised problem, scientific intelligence deserves attention of I. Bekh, A. Boiko, A. Bohush, M. Grynyova, V. Ilchenko, S. Klepko, V. Kurok, V. Kurylo, V. Luhovoho, P. Sauha, S. Sysoeva and others.

These are the academic and educational ideals of personality development, factors, criteria and conditions for socialization, conceptual approaches, principles, methods, forms, techniques and means of individual development, etc.

Thus, the issues of the development of personality innovative culture: modern philosophical and pedagogical discourse are becoming relevant.

The aim of the article. To characterize the peculiarities of innovative development dependtly on the availability of the necessary theoretical-methodological, methodological-technological basis for the development of person's innovative culture, both in professional and personal dimensions.

Results and discussions.

The term "development" is one of the most widely used in modern socio-humanitarian cognition. With the help of its semantic potential, the contents of all aspects of objective (material), subjective (ideal), biological (living) and social 
(community) being are examined and illuminated. At the casual level, the concept of "development" is commonly used as a synonym with other terms, such as "movement", "change", "genesis", "modernization", "reformation", "renewal", "improvement", "functioning", and its semantic load is associated with quality transformations, above all progressive content. The notion of "development" is of particular importance in the cognitive continuum of philosophy of education, educational, psychological and professional-pedagogical cognition. Within the framework of pedagogical discourse, the category of "development" is analyzed along with such concepts as "self-development", "becoming", "socialization", "correction".

Heuristic potential of modern philosophical concepts of development is of great scientific, conceptual-theoretical and methodological significance for understanding the problems of development of personality innovative culture. We are talking about dialectics and synergetics as a theory of development, as well as the scientific provisions of the new paradigm of sustainable development of mankind, that becomes the suppliers of the necessary philosophical-theoretical basis for designing and modeling the ways of development of innovative culture.

I. Dialectical understanding of the development of personality innovative culture. It is known that the basic philosophical theory of development is dialectics, according to which "development" is an objective, regular, directional, necessary and irreversible change of material and ideal objects which results in the new quality capable of self-motion and self-reproduction (Nadolny, Andrushchenko, Boychenko, \& Razumny, p. 222). Such attributes as absoluteness, versatility, focus, and irreversibility distinguish development from other changes. Dialectics emphasizes that development is a set of interrelationships, actions and relationships that are objective and universal. Development is a change in general that involves quantitative and qualitative transformations, the dynamics and nature of which are subordinated to the general ontological regularities.

In accordance with the principles of dialectical methodology, the development of innovative culture is a prerequisite for being innovative in today's society. It is carried out in accordance with the basic dialectical laws, including the law of transition of quantitative changes to qualitative ones, the law of unity and the struggle of opposites, and the law of negation of negation. The distinguished laws form the philosophical and theoretical basis for the development of the theory and methods of development of the innovative culture of modern personality. Dialectical understanding of ontological problems enables drawing attention to the fact that the development of the innovative personality culture is a process of developing invariant experience, which is carried out in internally contradictory processes of internalization - exteriorization. The process of assimilation of experience contains: direct basis, structures of object-sensory environment (everyday knowledge, individual-life experience) and rational theoretical knowledge. There is a dialectical connection between them: an orderly rational experience in the form of theoretical knowledge is integrated into the individual life, it is verified by practice and transformed into the structure of professional experience of innovative culture (Shumakova, 2008, p. 341).

Dialectical cognition makes enables scholars to examine and resolve the contradictions of the development of the personality innovative culture. They are, first and foremost, between: the existentially driven need of modern society for innovation and the immanent person's fear of a new, reflexive rejection of innovation; requests of the present for fundamentally new and non-standard solutions, content or projects, and dialectical requirement of preservation in any new significant "invariant" part, tradition; the dialectical principle of the need to accumulate a certain amount for the emergence of the new quality and the dynamic changes of the 21 st century, unpreparedness and prudent pace of life, etc.

The dialectical model of the world places the emphasis on the gradual development, its contradiction and ambiguity. It poses the question of whether it is possible to completely shape personality innovative culture. We agree with V. Tsvetkova's opinion that the process of the innovative personality culture development is much more complicated than the mechanical formation of a set of certain qualities and traits. Different environmental conditions, health factors and individual characteristics can greatly impede the formation of a "standard" innovator. The scientist believes that education can only delineate the general direction of the development of the innovative personality culture as a movement to enrich creativity and individuality. Formation of the "innovative person" lies, first and foremost, in the field of popularization in the society of innovations, development of constructive attitude of the society to innovations as individually and socially significant value. At the same time, the dialectical comprehension of the modern world clarifies that the development of the innovative personality culture is of fundamental importance for the development of the innovative society as a whole (Tsvetkova, 2009, p. 99).

Dialectical theory is important for considering ways to develop the innovative personality culture in the context of the acmeological-humanistic idea of continuing education and adult education. Dialectics views development as a continuous, absolute and systemic change of entities. The point is that the development of the innovative professional and pedagogical quality is largely determined by the objective continuity of education and self-education of an individual. The appearance of innovative components in the structure of the subjective experience of a teacher directly depends on his/her understanding the continuity of development as a key condition of being a person. Among the principles of the philosophy of life-long learning of a teacher, I. Ziazyun pointed out the following: professional-personal advance, based on the fact of the presence of human-forming potential in each individual; integration of pedagogical theory and practice in individual-personal experience; creativity of professional behavior; movement from holistic integrated characteristics of the teacher's personality to specific skills; a leading-edge paradigm that provides predictive training (Ziazyun, 2005, p. 17).

As it is regarded dialectics as a theory of development, we can consider the process of development of the innovative personality culture as an internally contradictory, necessary and natural phenomenon. Its demand is due to the objective demands of the present for an innovative resource, which is positioned as a key condition for the development of human capital. Taking into account the dialectical principles and laws of social development in the process of developing the theory and methodology of the development of the innovative personality culture will ensure their effectiveness and suitability for introduction into the broad educational process of training specialists.

II. Synergistic understanding of the personality innovative culture development. While analyzing the patterns of development of the modern world, finding and comprehending ways of development of the educational sphere in the context of modern globalization and multiculturalism, the new concept of the so-called modern determinism, synergetics, that 
etymologically, means cooperation, is placed first. Its methodological potential is of great importance for considering the nature and ways of the development of the innovative personality culture in the modern world. The scientific provisions of synergetics enables considering the latest educational and pedagogical sphere as a system of self-development and selfregulation.

Within the synergistic paradigm, the provisions on self-movement and self-organization of the educational system are constituted and substantiated. According to A. Yevtodiuk, the specific principles of development of modern education are openness, dynamism, nonlinearity, orderliness, integrity, structural, self-organized integrity of historically conditioned and interconnected views, beliefs, ideals, national traditions and practices, mutual motives and goals aimed at training and education of a person in order to achieve a certain level of education as a stage of becoming a person (Yevtodiuk, 2002, p. 2).

Among the basic ideas of synergetics as a theory of development for the interpretation of innovative culture, in particular, it is essential that there are always several alternative ways of changing any system in the world. Considering that innovations are immanent, natural and necessary signs of modernity, the way of development of personality innovative culture is determined by the system independently, it is not connected from the outside. That is why, in the terminological debate on the "formation" or "development" of the innovative personality culture, priority is given to development, since it emphasizes that innovation is not imposed, but is the content of the natural and the natural response to the needs and challenges of the 21 st century. The distinguished makes the educational task clear, which is not to form in a person a template of predefined qualities of an "innovator", but to create the necessary pedagogical conditions for the development and self-development of its innovative culture.

It is valuable to understand the contemporary specificity of the development of personality innovative culture and to refute the synergistic paradigm of established ideas about the linear nature of civilizational progress. Currently, it is becoming increasingly clear that the new quantitative changes do not always occur with certain quantitative fluctuations. Indeed, the mechanical accumulation of innovative cognitive tools in the individual and professional experience of a person will not necessarily lead to the emergence of a holistic innovative culture. Moreover, the reverse effects can also be observed today, when misrepresented innovations play a destructive role in the development of both human and social or economic systems.

Synergetic theory of development has enriched scientific knowledge with ideas about the nature and dynamics of the functioning of social systems. It was suggested that a complex organization emerges and self-sustains on the verge of chaos, in a dynamic transition zone between predictable order and unpredictable chaos (Klepko, 2003, p. 184). Such conclusions are consistent with the key features of the modern world: instability, chaos, dynamism and unpredictability. The proposed conclusions enable the statement of the need to develop and to implement a specially organized, pedagogically appropriate and orderly system of the development of the innovative personality culture. Moreover, synergetics states that the whole world is an objective order that results from the struggle of objectifications (aspirations, actions of the subject directed at the outside), often opposite and contradictory. Therefore, the development of innovative competence, which includes both the qualification and competence of an individual, as well as his/her innovative culture, skill and creativity, depends directly on the processes of self-organization, within which the necessary qualities of the individual innovator crystallize.

Synergetics called interaction and cooperation the key features of the development of the material and ideal world. According to its meta-narrative, the world is understood as an objective network of connections and relationships that set its own rules and its internal order. Such perceptions are relevant to the interactional nature of innovation, which can emerge solely as a result of the systematic interaction of all elements of innovative culture. Under the condition of the high level of innovative culture of society due to the systemic inter-correlation and inter-dependence of all its components, changing one causes an immediate change of the other. Instead, under the conditions of the stagnant innovative culture, a strong organizational and managerial impulse is needed, so-called. institutionalization of innovative culture, transformation of its development into an organized, orderly process with a well-defined structure of relations, rules of behavior, responsibility of participants, etc. (Yastrebov, Tsybikov, 2011, p. 162).

The specific terminological apparatus of synergetics, in particular such terms as "bifurcation", "nonlinearity", "open system", "attractor", etc., are of particular methodological importance for understanding the essence of the development of innovative culture. The valuable scientific ideas reveal that development is a collection of bifurcation points (choices), after which the open system must decide between several alternatives. As a result of such processes of self-organization, attractors are formed - structures, that are crystallized after the "damping" of transients. Such ideas help to understand and take into account the specifics of the development of the innovative personality culture, thus, they do not allow ignoring the objective conditions of functioning of educational systems.

For a scientifically correct understanding of the process of the development of the personality innovative culture, the synergistic position of self-development and self-support of any systems is of great interest. Therefore, self-learning and self-improvement are crucial in achieving a high level of innovative culture. On the one hand, innovative culture is the result of the purposeful activity of a subject himself/herself and is ensured by its self-improvement, on the other hand, it forms the subject activity itself. In this context, it is worth to mentioning that personality innovative culture must be developed first and foremost in the process of purposeful learning and professional activity, with the future acmeological setting for selfdevelopment and self-improvement (Shumakova, 2008, p. 290, 297).

III. The innovative personality culture in the context of the paradigm of the sustainable development of mankind. If scientists consider the essence of development within the framework of dialectical and synergetic paradigms, then the concept of sustainable development of mankind, which finally acquired its appearance in the 1980s, is devoted to discussions about its purpose and direction. Its main task is to achieve such a level of development when meeting the needs of the present generation will not jeopardize the ability of future generations to meet their needs (Gizatullin, Troitsky, 1998, p. 124). Specification of sustainable development objectives was made in the UNO General Assembly Resolution on "Transforming our World. Transforming our world: the 2030 Agenda for Sustainable Development", approved in 2015. It outlined seventeen global goals, including: quality education, gender equality, reducing inequality, clean energy, partnership and more. The UNO defined Sustainable Development Coordinates were implemented in the Presidential Decree "On the 
Sustainable Development Goals of Ukraine for the Period up to 2030" (Presidential Decree “On Sustainable Development Goals of Ukraine for the Period up to 2030": No. 722/2019).

It is important to emphasize that the concept of sustainable development is socially oriented. It aims at maintaining social and cultural stability, reducing the number of destructive conflicts (Gizatullin, Troitsky, 1998, p. 128). The priority of the sustainable development strategy is innovation, which is based on the active use of knowledge and scientific achievements, stimulation of innovative activity, creation of favorable investment climate and so on. The absolute purpose of sustainable development is personality, the provision of decent living conditions and work (Ukraine's 2030 Sustainable Development Strategy. Draft, 2017, p. 6-7). An integral part of achieving the benchmarks and indicators of sustainable development is the education reform, within which the formation of the innovative culture of educators and organizers of education is a priority.

The philosophy of sustainable development determines educational guidelines, becomes a supplier of components of the innovative personality culture, and determines the list of necessary qualities that an innovative personality should possess. In our opinion, the set of personality traits that determine the formation of innovative culture can be grouped into three groups, including axiological-reflexive, creative-prognostic and cognitive-practical. It is about developing the readiness of an individual to perceive and produce innovations, to realize them as a necessary condition for being in the modern world, to enrich their creativity, ingenuity, sociability and so on.

The development of personality innovative culture is procedural, it requires regulation, development of appropriate technology, forms, methods and means. The highlighted is reflected in the technological component, which means an algorithmic system of actions and measures, leading to the successful solution of a complicated problem through an unusual approach, non-standard assessment of the situation, the use of new methods. Development of technologies for the development of innovative culture involves the analysis of previous experience, the development of algorithms and programs for modeling and stimulation of the creative process, practical use and evaluation of the quality of creative results, etc. (Kozlova, Milenkova, 2007, p. 37). In our opinion, the dialectical and synergistic understanding of development requires that the constructive and technological block of development of personality innovative culture should contain the following stages: motivational-cognitive, professional-practical, creative-active and professionally-relevant. The interdependence and interaction will allow them to build appropriate regulatory and procedural coordinates that will ensure the efficiency and ergonomics of personality innovative culture.

Conclusions. Thus, modern theories of social development enable revealing peculiarities of the development of personality innovative culture. The distinguished lead to the conclusion that the development of innovation and personality innovative culture is a natural, necessary, historically conditioned and self-organized process of objectification and institutionalization of the innovative content at the social and individual levels. It is important to understand that the emergence of innovation and personality innovative culture is possible only in the light of the dialectical and synergistic nature of being. Openness of educational systems, presence of environment and mechanisms for the natural struggle of mutually contradictory and opposing forces, absence of authoritarian and artificial interventions in the processes of institutionalization of personality innovative culture is important for the formation of innovative culture. Currently, the main task of national education is to legitimize in the society the idea of the need for innovation and the importance of formation and development of the personality innovative culture, to translate innovation from the status of a trending term into the objective, conscious society and government of the vital need of the 21 st century.

Perspectives of the further research. The rethinking and enrichment of the personality innovative culture as a multifaceted and specific process, whose demand and success depends on a number of socio-cultural and global political conditions, such as the level of the STP, state policy, peculiarities of religious life, etc. are refered to the perspectives of the further research.

\section{References}

Gizatullin, Kh. N, \& Troitsky, V. A. (1998). The concept of sustainable development: a new socio-economic paradigm. Social Sciences and Modernity, 5, 124-130.

Klepko, S. F. (2003). Methodology of education cognition: to organize chaos. Practical philosophy, 1, 183-190.

Kozlova, O. G., \& Milenkova, R. V. (2007). Innovative culture: essence characteristics: monograph. Sumy: Sumy State University A. S. Makarenko.Nadolny, I. F. (Ed.). (1997). Philosophy: a textbook. Kyiv: Vicar, 1997.

On approval of the Strategy for the Development of the Sphere of Innovative Activity for the period till 2030. Retrieved from https://zakon.rada.gov.ua/laws/show/526-2019-\%D1\%80 (accessed: 01/15/2020).

Presidential Decree “On Sustainable Development Goals of Ukraine for the Period up to 2030”: No. 722/2019. Retrieved from https://www.president.gov.ua/documents/ 7222019-29825 (accessed: 01/15/2020).

Shumakova, O. A. (2008). Acmecological self-improvement strategies of personality innovative culture in the process of professionalization. Scientific works of the Russian State Pedagogical University after A. I. Herzen, 81, $289-297$.

Shumakova, O. A. (2008). Development of professional experience as a substructure personality innovative culture. Russian News State Pedagogical University named after A. I. Herzen, 87, 337-343.

Tsvetkova, V. D. (2009). Formation of the personality innovative culture: philosophical aspect. Omsk Scientific Herald, 1 (75), 97-99.

Ukraine-2020 Sustainable Development Strategy: approved by Presidential Decree of January 12, 2015 No. 5/2015. Retrieved from https://zakon5.rada.gov.ua/ laws / show / 5/2015 (accessed: 01/15/2020).

Ukraine's $2030 \quad$ Sustainable Development Strategy. Draft $\quad-\quad 2017 . \quad 112 \quad$ p. Retrieved from https://www.undp.org/content/dam/ukraine/docs/SDGreports/UNDP_Strategy_v06-optimized.pdf(accessed: 01/15/2020). 
Weizsaker, E., Wykman, A. (2019). Come on! Capitalism, shortsightedness, population and the destruction of the planet. Report of the Roman Club. Kyiv: Summit Book.

Yastrebov, K. L., \& Tsybikov, D. N. (2011). Features of innovative development and innovative culture. IRGTU Gazette, 7 (54), $161-164$.

Yevtodiuk, A. V. (2002). Synergetic principles of educational systems modeling (Extended abstract of PhD diss.). Kyiv.

Ziazyun, I. A. (2005). The philosophy of pedagogical quality in the system of continuous education. Bulletin of Zhytomyr Ivan Franko State University, 25, 13-18.

козлов д.

Сумський державний педагогічний університет імені А. С. Макаренка

\title{
РОЗВИТОК ІННОВАЦІЙНОї КУЛЬТУРИ ОСОБИСТОСТІ: СУЧАСНИЙ ФІЛОСОФСЬКО- ПЕДАГОГІЧНИЙ ДИСКУРС
}

Статтю присвячено визначенню сутності процесу розвитку інноваційної культури особистості. Вивчено феномен інноваційної культури майбутнього керівника закладу освіти. У дослідженні розглянуто місце інноваційної культури майбутнього керівника закладу освіти в системі складових інноваційної особистості. Приділено увагу розкриттю діалектичного та синергетичного розуміння інноваційної культури особистості. Схарактеризовано інноваційну культуру особистості у контексті парадигми сталого розвитку людства. Зазначено, що освітня система будь-якої країни становить національний фундамент інноваційного розвитку суспільства. Лише високий рівень освіти забезпечує значні темпи інноваційного прогресу. Про що свідчить стрімкий розвиток країн з розвиненими освітніми системами, які здійснили значний інноваційний прорив саме завдяки потужному поступу у застосуванні новітніх освітніх технологій та принципів. Наголошено на розвитку інноваційної культури особистості у контексті національного філософсько-педагогічного дискурсу.

Ключові слова: розвиток; сталий розвиток; інновація; інноваційна культура особистості; діалектичні та синергетичні засади розвитку інновачійної культури особистості

Стаття надійшла до редакції 19.11.2019 р.

УДК 811.161.2+821.161.2]:378.09:004

DOI: https://doi.org/10.33989/2075-146x.2019.24.194847

НАТАЛІЯ КОНОНЕЦ

ORCID ID 0000-0002-4384-1198

ВНЗ Укоопспілки «Полтавський університет економіки і торгівлі»,

ОКСАНА ЛИТВИНОВА

ORCID ID 0000-0002-3935-029X

\section{ТЕТЯНА МАРЮХНIЧ}

ORCID ID 0000-0001-5891-2844

Коледж управління, економіки і права Полтавської державної аграрної академії

\section{РЕАЛІЗАЦІЯ РЕСУРСНО-ОРІЄНТОВАНОГО НАВЧАННЯ ПРИ ВИВЧЕННІ УКРАЇНСЬКОЇ МОВИ ТА ЛІТЕРАТУРИ}

\begin{abstract}
У статті презентовано результати досвіду створення освітніх сайтів та дистанційних курсів для реалізації ресурсно-орієнтованого навчання, яке тлумачиться як цілісний динамічний процес організації і стимулювання самостійної пізнавальної діяльності студентів із оволодіння навичками активного перетворення інформаційного середовища, засвоєння студентами знань із дисциплін «Українська мова», «Українська література», «Українська мова за професійним спрямуванням» 3 урахуванням інформаційних потреб обраної освітньої програми, який передбачає оптимальне використання тріадою «студент-викладач-бібліотекар» інформаційних ресурсів. Визначено основні напрями реалізації ресурсно-орієнтованого навчання при вивченні української мови та літератури.
\end{abstract}

Ключові слова: ресурсно-орієнтоване навчання; процес навчання; концепція; електронний освітній ресурс; дистанційний курс

Постановка проблеми. Сучасним напрямом розвитку вищої та фахової передвищої освіти в Україні є докорінне оновлення їі змісту відповідно до вимог чинних стандартів, освітніх програм, орієнтованих на підвищення якості підготовки фахівців, які повинні мати фундаментальні професійні знання, вміти здобувати їх самостійно і бути конкурентноспроможними на вітчизняному ринку праці. Такі важливі нормативні документи, як Закон України 